\title{
KONSEP MANCAPAT-MANCALIMA DALAM STRUKTUR KOTA KERAJAAN MATARAM ISLAM Periode Kerajaan Pajang Sampai Dengan Surakarta
}

\author{
Junianto \\ Program Studi Arsitektur, Fakultas Teknik, Universitas Merdeka Malang \\ junianto@unmer.ac.id
}

\begin{abstract}
ABSTRAK
Unsur-unsur kota tradisional di Jawa pada masa kerajaan Mataram Islam, antara lain berupa Keraton, Alun-alun, Masjid, Pasar dan sejumlah permukiman Abdi-dalem. Susunan unsur-unsur kota tersebut, didasari keyakinan kosmologi Jawa yang bersumber dari kepercayaan Hindu-Budha. Kerajaan Mataram Islam bermula di Pajang dan berakhir di Surakarta dan Yogyakarta. Perpindahan kota kerajaan Mataram Islam mulai dari Pajang, Kotagede, Plered, Kartasura, hingga Surakarta, menunjukkan gejala pergeserah struktur kotanya. Kajian ini bertujuan mengidentifikasi pergeseran atau perubahan struktur kota kerajaan Mataram Islam, dalam implementasi konsep mancapat-mancalima. Gambaran struktur kota kerajaan Mataram islam, dilakukan dengan metode deskriptif-ideographik, melalui analisis dokumen peta atau denah dan keterangan sejarah. Penggunaan metode ini, dimaksudkan untuk menggambarkan makna struktur atau susunan unsur-unsur kota kerajaan Mataram Islam, yang menjadi struktur kota awal. Identifikasi konsep mancapat-mancalima yang menjadi ciri kota Jawa, cukup signifikan sebagai struktur kota awal dalam menelusur perkembangan kota sekarang.
\end{abstract}

Kata Kunci: konsep struktur kota tradisional, mancapat, kota surakarta

\begin{abstract}
$A B S T R A C T$
The elements of a traditional city in Java during the Islamic Mataram kingdom, including the Palace, Alun-alun, Mosque, Market and a number of Abdi-dalem settlements. The composition of the elements of the city, is based on Javanese cosmological beliefs originating from Hindu-Buddhist beliefs. The Islamic Mataram Kingdom began in Pajang and ended in Surakarta and Yogyakarta. The movement of the Islamic Mataram royal city starting from Pajang, Kotagede, Plered, Kartasura, to Surakarta, showed symptoms of a shift in the structure of the city. This study aims to identify shifts or changes in the structure of the Islamic Mataram royal city, in the implementation of the mancapat-mancalima concept. The description of the structure of the Islamic city of Mataram, carried out with a descriptive-ideographic method, through analysis of map documents or floor plans and historical information. The use of this method, is intended to illustrate the
\end{abstract}


meaning of the structure or arrangement of elements of the Islamic Mataram royal city, which became the initial city structure. The identification of the mancapat-mancalima concept that characterizes the city of Java is quite significant as the initial city structure in tracking the city's current development.

\section{Keywords: traditional city structure concept, mancapat, Surakarta city}

\section{PENDAHULUAN}

Kerajaan Mataram Islam, berdiri setelah kerajaan Demak berakhir. Pusat kerajaan tersebut berawal di Pajang, yang berada di wilayah sebelah barat Kota Surakarta. Seiring pergantian penguasa, pusat kerajaan berpindah-pindah, mulai dari Pajang, Kotagede, Plered, Kartasura, hingga berpindah di Surakarta. Jejak perpindahan pusat kerajaan Mataram Islam tersebut, menunjukkan unsur-unsur kota yang sama, berupa Keraton, Alun-alun, Masjid, Pasar, rumah-rumah bangsawan dan permukikan abdi-dalem.

Sistem kekuasaan raja di Jawa, memiliki bentuk yang bercorak sakral, dalam konsepsi wahyu atau dikenal dengan "Dewa - Raja" (Santoso, 1984). Berlatar legitimasi sakral tersebut, konsepsi kota-kota yang tumbuh dari sebuah pusat kerajaan, niscaya berlandaskan konsepsi religius-budaya. Keraton dan raja dalam hal pranata kehidupan masyarakatnya, berperan menjadi pusat kebudayaan. Kekuasaan raja bersifat mutlak dan tidak mengenal institusi hukum yang independen. Seiring berjalannya pemerintahan Keraton dan kehidupan masyarakat kota dengan puncak kekuasaan raja, terbangunlah pola struktur kota, yang berciri khas unik (Junianto, 2017:27). Sistem kekuasaan raja tersebut, mempunyai 'daya bentuk' yang sangat kuat terhadap pola struktur kota. Penelusuran struktur kota awal (tradisional) bertujuan mendapatkan identitas "kota Jawa" dan unsur-unsurnya, yang signifikan berpengaruh dalam pola transformasinya.

Pemahaman masyarakat tentang "kota", berbeda antara yang satu dengan lainnya, juga dari kurun waktu satu dengan lainnya. Dalam masyarakat Jawa tradisional misalnya, pemahaman 'kota' diabstraksikan dengan sebutan kutha, yakni suatu lingkungan berpagar bata atau tembok. Lingkungan di dalam tembok tersebut, merupakan tempat tinggal pimpinan 'negara' atau wilayah, para pejabat, serta para abdi (pegawai). Pemahaman kutha tersebut, kemudian mengalami perubahan, seiring munculnya simbol-simbol pengganti unsur-unsur fisik. Pengertian kutha, selanjutnya diartikan sebagai papan padunungan atau tempat pimpinan 'negara' atau wilayah, tanpa harus dibatasi tembok. Penggambaran kota, juga bisa dilihat secara morfologis. Morfologi kota merupakan pendekatan secara fisik, dengan mengkaitkan latar sejarah pembentukan unsur-unsur kota tersebut. Sebagai artefak, kota memiliki bentuk fisik yang berlatar ungkapan peradaban-kebudayaan masyarakat 
penghuninya. Dari jejak pusat-pusat kerajaan Mataram Islam, kota Surakarta berbeda jaman dengan sebelumnya. Pajang, Kotagede, Plered dan Kartasura, merupakan kota-kota kerajaan Mataram Islam pra-kolonial. Kota Surakarta berdiri pada masa kolonial Hindia Belanda, tumbuh berkembang dalam kolase aneka budaya, sangat menarik untuk dikaji perbandingan struktur kotanya dengan Pajang, Kotagede, Plered maupun Kartasura. Perkembangan kota Surakarta, niscaya berbeda dengan pusat kerajaan Mataram Islam lainnya.

Penelitian kota-kota bersejarah, seperti halnya jejak pusat kerajaan Mataram Islam, perlu dilakukan, mengingat peran kerajaan tersebut dalam budaya Jawa dan pranata kehidupan tradisional. Hal tersebut juga karena perkembangan kota semakin pesat, khususnya di kota Surakarta dan Kotagede. Perkembangan kota sebuah keniscayaan, sebagai upaya pemenuhan penciptaan ruang kehidupan yang lebih baik. Disisi lain, pemahaman sejarah awal pembentukan kota sangatlah penting, sebagai titik tolak perencanaan masa datang.

Kerajaan Mataram Islam merupakan jejak yang sangat penting di Jawa, mengingat semasa kejayaannya pernah menguasai sebagian besar wilayah Indonesia saat ini, Selain itu, kurun waktu pemerintahan yang sangat lama, menanamkan budaya yang cukup kuat. Surakarta merupakan salah satu kota kerajaan Mataram Islam, yang tumbuh berkembang bersamaan dengan kolonial Hindia Belanda. Penelusuran konsep kosmologi mancapatmancalima di kota Surakarta, yang berlatar spiritual
Jawa, tidak bisa lepas dengan pusat-pusat kerajaan Mataram Islam lainnya. Namun demikian, pusatpusat kerajaan Mataram Islam pra-kolonial, sebenarnya lebih besar dilatarbelakangi oleh kebudayaan pra-Islam.

Pusat-pusat kerajaan Mataram Islam yang menjadi fokus penelitian ini, berawal dari perpindahan Keraton Pajang ke Kotagede, sekitar tahun 1587. Kota-kota bekas pusat kerajaan tersebut, secara keseluruhan mempunyai ciri yang sama sebagai kota kerajaan Islam. Ciri yang umum adalah adanya Alunalun dengan Masjid di sebelah baratnya, serta Keraton. Walaupun mengikuti pola kota kerajaan Mataram Islam secara umum, namun pada kenyataan terdapat perbedaan satu dengan lainnya. Perbedaan tersebut terjadi dan dilatarbelakangi oleh struktur sosial masyarakatnya yang berbeda. Pada kasus kota Surakarta, telah banyak pengaruh dari fasilitas pemerintah Hindia Belanda. Pengaruh budaya pra-Islam di Kotagede, juga menunjukkan pola bentuk struktur kota yang berbeda dengan kota lainnya. Rapoport (dalam Catanese, 1986) merumuskan kesimpulan umum, bahwa kota selalu mempunyai struktur dan bentuk. Perbedaan satu dengan lainnya, hanyalah pada sifat penataan, hirarki dan morfologinya.

Implementasi konsep mancapat-mancalima dalam struktur kota kerajaan Mataram Islam, terpancang pada sejarahnya dan dalam latar budayanya (Murtiyoso, 1993). Kajian terhadap implementasi konsep ini dan maknanya, sangat penting bagi upaya pemahaman karakter kota-kota bersejarah tersebut. 
Dengan mengetahui struktur kota awal terbentuknya suatu kota, akan menentukan arah perkembangan kota tersebut kemudian hari. Kolase unsur-unsur kota dalam strukturnya, dapat dibaca sebagai latar budaya dan dalam konteks unsur-unsur kota tersebut. Berdasarkan hal tersebut, terdapat permasalahan yang menarik untuk dikaji, yaitu : pertama, struktur kota kerajaan Mataram Islam, tersusun dari unsur-unsur apa saja (?); kedua, apa makna konsep mancapat-mancalima dalam struktur kota tersebut (?).

\section{KOTA KERAJAAN MATARAM ISLAM}

Fenomena sebuah kota, terlebih berlatar sejarah kerajaan besar, merupakan hal yang komplek dan memerlukan kajian dari bebagai disiplin ilmu. Dalam kajian sejarah, Suratman (1989) meneliti kehidupan dunia keraton Surakarta antara tahun 1830-1939. Penelitian disertasi tersebut, mengungkap gambaran kehidupan orang-orang di dalam keraton dan juga masyarakat Surakarta yang terkait dalam sistem kehidupan kehidupan keraton tersebut. Dalam kajian ini, dipaparkan berbagai aspek kehidupan, meliputi aspek sosial, ekonomi, politik, kultural dan juga unsur-unsur kotanya. Pola komunitas keraton, terjadi struktur yang menyangkut berbagai dimensi.

Dalam bidang Arkeologi, Sumarlina (1993) meneliti pola tata kota Surakarta, pada awal berdiri dan perkembangannya. Dalam kajian tersebut, digambarkan bahwa pola tata kota Surakarta direncanakan berdasarkan konsep kosmologi. Keraton sebagai pusat, dikelilingi oleh permukiman yang menyebar ke arah empat mata-angin. Pola tersebut membentuk suatu lingkaran, sekaligus menjadi ciri kota Surakarta.

Kosmologi keraton Surakarta, secara imajiner berupa lingkaran-lingkaran, dengan pusatnya adalah keraton (Behrend, 1982). Lingkaran-lingkaran tersebut secara konsentrik menunjukkan tingkatan area yang hirarkis. Keraton dianggap sebagai pusat 'dunia' atau makrokosmos. Bangsal Prabayasa sebagai tempat kedudukan raja, berbentuk bangunan Joglo, melambangkan Meru, dan raja dianggap sebagai titisan dewa berperan menjaga keseimbangan alam. Konsep tersebut sejaran dengan kajian Santoso (1984) perihal tata ruang 'negara' Mataram Islam. Ruang kota Surakarta berdasar konsep kosmologi, terbagi menjadi dua kutub yang bersifat sakral dan profan (Santoso, 1984). Daerah di sebelah utara alun-alun Utara dianggap bersifat profan, sedangkan daerah di sebelah selatan alun-alun Utara bersifat sakral.

Konsep mancapat-mancalima dalam struktur kota kerajaan Mataram Islam pada kajian ini, merupakan content analysis terhadap makna struktur kota awal yang berlatar magis sakral. Unsur-unsur kota yang tersusun berdasar konsep kosmologi, menunjukkan penggambaran budaya yang bernilai historis tinggi. Kajian ini bertujuan untuk mendapatkan gambaran makna konsep mancapat-mancalima dalam struktur kota kerajaan Mataram Islam, sekaligus menjadi ciri khasnya. Penelitian yang mendasari kajian ini, bersifat mendeskripsikan latar belakang budaya terjadinya tata fisik struktur kota bekas pusat kerajaan Mataram Islam. Mendeskripsikan atau 
menggambarkan, merupakan keinginan untuk melihat fenomena pada keseluruhan latar yang menjadi kasus penelitian (Muhadjir, 1990:138).

Penataan ruang pada masa kerajaan Mataram Islam, mengenal suatu hubungan yang mempunyai struktur tertentu antara negara agung (pusat) dan mancanegara. Penerapan secara ketat perihal penataan tersebut, terjadi pada masa abad ke-16 hingga abad ke-18 (Santoso, 1984). Tata ruang 'negara' Jawa masa kerajaan Mataram Islam, terbagi dalam sistem lingkaran, dengan empat radius berbeda secara hirarkis (Soemardjan, 1991). Raja berkedudukan sebagai pusat sistem, secara simbolik sebagai satu-satunya segala kekuasaan dan kewibawaan. Raja dianggap memiliki segala sesuatunya di dalam 'negara'. Kehormatan dan kedudukan, keadilan dan wibawa, kebijaksanaan dan kesejahteraan, kesemuanya menjelma dalam diri sang raja.

Secara keruangan, raja identik dengan Keraton, yang secara kosmologis merupakan lingkaran pusat bagi 'negara'. Dalam lingkaran pusat tersebut, menjadi tempat tinggal raja bersama keluarganya. Keraton selain berfungsi sebagai tempat tinggal raja. Juga sebagai tempat kedudukan administrasi dalam (parentah jero). Administrasi dalam merupakan lembaga pengatur lingkungan di dalam benteng Keraton dan juga sekaligus menjadi penghubung antara raja dengan administrasi luar atau parentab jaba (Junianto, 2016).

Dalam struktur tata ruang 'negara' Mataram Islam, sebagai ibukota berada di lingkaran (imajiner) kedua.
Daerah lingkaran kedua ini, sering disebut 'negara', sebagai tempat bermukim kaum bangsawan, pejabat tinggi keraton, Masjid, Alun-alun, serta bangunanbangunan penting lainnya. Lingkaran ketiga, disebut negara agung (tanah suci). Wilayah negara agung dibagi menjadi sejumlah tanah gadhuh yang berstatus hak guna pakai. Lingkaran ke-empat dalam sistem hirarki tata ruang negara Mataram, disebut daerah mancanegara. Wilayah mancanegara ini, dipimpin oleh beberapa orang bupati yang merupakan bawahan langsung dari Patib Dalem (Santoso, 1984).

Pengertian "lingkaran pusat" dalam hirarki tata ruang kerajaan Mataram tersebut, lebih bersifat ruang kosmis yang abstrak. Semua kekuatan magis dan kosmis, dilambangkan dalam bentuk pusaka kerajaan. Pusat kosmis, dengan demikian memiliki arti kekuatan magis (pusaka) tersebut. Lingkaran pusat, berupa 'Dalem' (Keraton) diartikan sebagai tempat pusaka, bukan sekedar tempat tinggal raja. Pemisahan keruangan antara Dalem Keraton dengan bagian-bagian lainnya di dalam negara, didasari oleh sifat kesakralan tersebut. Berdasar konsep demikian, kedudukan Keraton, Alun-alun dan Masjid, merupakan bagian yang sakral dari wilayah negara. Dalam wilayah negara, pada bagian lainnya bersifat profan duniawi. Dalam wilayah profan ini, terdapat antara lain Kepatihan, pasar, permukiman abdi-dalem termasuk prajurit, serta permukiman penduduk.

Penataan ruang 'negara' Mataram Islam, dapat dianggap sebagai dua sistem hirarkis yang tumpang tindih (superimposed). Sistem lingkaran yang pertama, terdiri dari tiga garis imajiner keruangan yang 
dianggap sakral, yaitu lingkaran batas Dalem, lingkaran batas komplek Keraton dan batas negara agung. Sistem lingkaran kedua, juga terdiri dari tiga garis imajiner keruangan, bersifat profan duniawi. Lingkaran profan ini, meliputi lingkaran batas komplek Keraton (parentah jero), lingkaran batas 'negara' (pusat birokrasi kerajaan) dan lingkaran batas mancanegara. Superposisi dari kedua sistem lingkaran tersebut, melambangkan azas penataan ruang negara Mataram Islam (Santoso, 1984).

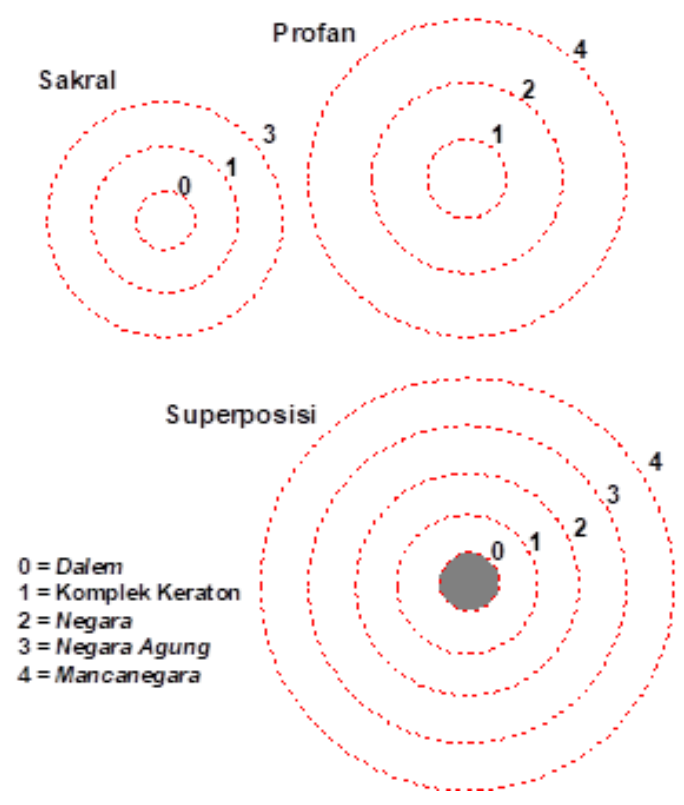

Gambar 1 : Lingkaran Tata Ruang Negara Mataram Sumber : Santoso, 1984

\section{KEHIDUPAN DAN SIMBOLISME MASYARAKAT JAWA}

Pada masa kerajaan Mataram islam, masyarakatnya kental dengan latar budaya Jawa, yang merupakan kulturasi sejak lama, sebelum kerajaan Islam. Masyarakat Jawa beranggapan bahwa kehidupan di dunia merupakan bagian dari kesatuan eksistensi, yang mencakup segalanya. Dalam kesatuan tersebut, semua gejala mempunyai tempat dan berada dalam hubungan yang saling melengkapi dan terkoordinasi satu sama lain (Mulder, 1985:19). Keyakinan masyarakat Jawa ini, menjadi konsep dasar dalam upaya masyarakat menuju keselarasan tatanan. Keselarasan tersebut, tidak hanya manusia (mikrokosmos) dengan makrokosmos, tetapi juga keselarasan di dalam diri manusia itu sendiri. Kegiatan manusia, diutamakan untuk mempertahankan keselarasan ini di dalam lingkungan hidupnya. Gangguan terhadap mikrokosmos dan makrokosmos, dianggap juga sebagai gangguan atas alam semesta.

Dalam ajaran-ajaran Jawa, dikenal penuh dengan simbolisme, yang memacu angan dan renungan. Ajaran tersebut, juga terkandung dalam mitologi wayang purwa, yang diilhami oleh Mahabarata. Kehidupan di dunia dianggap hanya merupakan pencerminan semata. Kehidupan harafiah, diyakini sebagai suatu bayangan dari kebenaran dan kejadiankejadian yang lebih tinggi. Dalam konsepsi tatanan kehidupan di 'dunia' tersebut, berkaitan dengan tatanan kehidupan negara (Mangunwijaya, 1988:129). 
Negara dalam pandangan masyarakat Jawa pada masa kerajaan, dapat berarti Keraton. Negara klasik semacam ini, menurut Gesick (1989), tidak diperintah atau diatur dengan sangat sistematik. Masyarakat hidup dalam kekuatan alam simbolik, demi menjaga keutuhan tatan negara. Tatanan kehidupan masyarakat tradisional Jawa, juga dipengaruhi oleh sistem religi yang bersumber dari Keraton. Pandangan masyarakat Jawa terhadap masalah-masalah dasar dalam hidupnya, senantiasa dikaitkan dengan sistem religiusnya. Masyarakat Jawa, sebelum masuknya Hindu dan Budha, telah meyakini adanya kekuasaan di luar matra dirinya. Keyakinan ini seringkali dinamakan Agama asli yang bersifat animisme. Segala keberhasilan dan kegagalan dalam hidup, diyakini sebagai karunia atau kemurkaan dari kekuasaan tersebut.

Kekuasaan tersebut, seringkali dilaitkan dengan kekuasaan alam. Dengan alasan ini, masyarakat Jawa beranggapan bahwa manusia hidup harus berusaha untuk membina hubungan harmonis dengan alam (Koentjaraningrat, 1992). Dalam menjalani hidup dengan keyakinan tersebut, masyarakat Jawa mengenal sistem klasifikasi simbolik. Sistem-sistem tersebut, adalah seperti dikenal dengan klasifikasi simbolik berkategori dua, tiga, empat, lima, tujuh dan sembilan. Sistem klasifikasi simbolik dalam kehidupan masyarakat Jawa, dapat ditelusuri berdasarkan pada sistem kategori dua, tiga, lima dan sembilan (Ronald, 1988 : 65). Disisi lain, manusia Jawa mengenal juga sistem klasifikasi simbolik yang berdasarkan pada kategori empat, enam dan delapan.

Sistem klasifikasi simbolik berkategori dua, dalam pandangan manusia Jawa, menggambarkan adanya hal-hal berlawanan. Sifat-sifat berlawanan dapat berupa antara lain baik-buruk, keras-lemah, positipnegatip, dan sebagainya. Sistem simbolik berkategori dua ini, seringkali digunakan dalam perwujudan bangunan. Sistem klasifikasi simbolik berkategori tiga merupakan pengembangan kategori dua. Sifatsifat berlawanan yang terdapat dalam kategori dua, dikembangkan dengan penambahan di pusatnya. Keberadaan pusat tersebut dimaksudkan sebagai penetral terhadap sifat berlawanan, agar tercapai keseimbangan. 

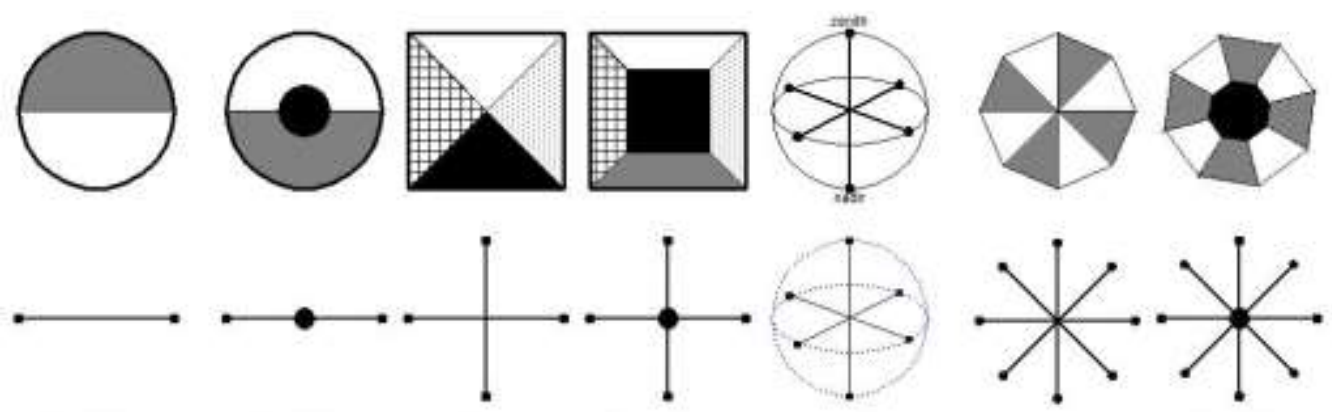

KATEGORi a

KATEGORI A
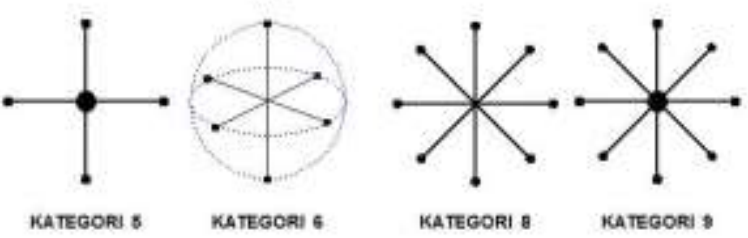

Gambar 2. : Sistem Klasifikasi Simbolik Tradisional Jawa.

Sumber : Tanudjaya, 1991: 40.

\begin{abstract}
Sistem klasifikasi simbolik berkategori empat, menunjuk kepada arah mata angin. Dalam masyarakat Jawa, sistem simbolik ini sering dipadukan dengan sistem simbolik berkategori lima, dikenal dengan nama mancapat dan mancalima. Sistem klasifikasi simbolik ini dikembangkan dari pandangan manusia Jawa akan kosmos. Keempat penjuru mata angin, diyakini sebagai tempat bertahtanya para dewa. Sistem klasifikasi simbolik berkategori lima, mengandung arti kemantapan dan keselarasan dunia. Klasifikasi simbolik berkategori lima ini, dalam masyarakat Jawa dikenal sebagai konsep mancalima. Mancalima merupakan pengembangan sistem klasifikasi simbolik berkategori empat, dengan penambahan satu titik pusat (Tjahjono, $1988: 40$ ).
\end{abstract}

Sistem klasifikasi simbolik berkategori enam berasal dari kepercayaan Islam. Hal ini menyangkut enam dasar kepercayaan, yakni kepercayaan terhadap Allah, Malaikat, Kitab, Rasul, Hari kiyamat, dan Takdir. Klasifikasi simbolik berkategori enam ini, tidak banyak dipergunakan oleh masyarakat Jawa tradisional umumnya. Sistem klasifikasi simbolik berkategori tujuh, berkaitan dengan sistem simbolik berkategori enam, dengan tambahan satu unsur sebagai pusatnya.

Sistem klasifikasi simbolik berkategori delapan, merupakan pengembangan kategori empat. Sistem ini dikembangkan dari konsep empat mata-angin, dengan penambahan kombinasi arah antaranya. Sistem seperti ini, banyak ditemukan pada masyarakat Jawa, yang dipengaruhi oleh kepercayaan Hindu-Budha, serta budaya Cina. Ajaran Hindu 
mengenal pola Mandala, yang terdiri atas delapan kali delapan divisi. Budaya Cina mengenal delapan penjuru mata angin. Sistem klasifikasi simbolik berkategori sembilan, dikembangkan dari konsep empat mata angin. Dari konsep empat mata angin, berkembang dengan penambahan kombinasi arah antaranya, serta penambahan satu unsur sebagai pusatnya. Konsep ini dipakai juga dalam masyarakat tradisional Bali. Masyarakat Jawa, banyak mempergunakan konsep simbolik berkategori sembilan ini, sebagai simbolisasi konsep wali sanga.

\section{PROSES PEMBENTUKAN UNSUR-UNSUR KOTA KLASIK JAWA}

Kota-kota pada masa kerajaan, yang menjadi pusatpusat kerajaan Mataram Islam, pada umumnya mempunyai sifat a-historis. Bentuk inti kota semacam ini, tidak terdiri atas sejumlah rumah atau kelompok rumah yang terkonsentrasi pada suatu tempat. Kota juga bukan sekedar terdiri atas rumah dan gedung-gedung, jalan dan taman yang terencana dalam kaidah seni bangunan. Sebuah kota klasik Jawa pada masa kerajaan Mataram Islam, tersusun atas bangunan dan taman yang diatur berlandaskan adat-istiadat yang bersumber dari Keraton (Santoso, 1984).

Dalam masyarakat Jawa tradisional, masih meyakini adanya kekuatan "pusat" berupa Keraton, yakni tempat tinggal Raja. Raja dengan Keraton-nya, secara simbolis dianggap sebagai tempat mengikatkan diri. Masyarakat Jawa tradisional, merasa tidak mempunyai eksistensi diri, jika tidak mengikatkan diri dengan kerajaan. Kerajaan dalam ikatan demikian, sering disebut sebagai pusat kebudayaan.

Bentuk pengikatan diri masyarakat Jawa tersebut, adalah dengan mengikuti segala sesuatu yang dianut, dilakukan, dan menjadi tata hidup serta tata nilai, di lingkungan kerajaan. Sebagai contoh adalah bahasa, tata cara adat memperingati kelahiran, perkawinan serta kematian, pakaian, dan bahkan membangun rumah tinggal. Dengan berlatar belakang keyakinan tersebut, terjadi "permukiman" Jawa yang memiliki pusat secara imajiner (Junianto, 2016). Sebagai pusatnya adalah raja, atau manifestasi simbolik dari raja.

Dalam implementasi tata permukiman masyarakat Jawa, dikenal hirarki ruang. Tempat tinggal seseorang yang menjadi menifestasi dari raja, menjadi pusat kesatuan permukiman, berstatus paling tinggi. Ruang-ruang lainnya, membentuk lingkaran-lingkaran imajiner, secara berhirarkis berstatus semakin rendah. Sistem tata nilai tersebut, dalam permukiman Jawa, kemudian dikenal bentuk Magersari, yang secara harafiah berarti mengindung kepada "sesembahan" (Junianto, 2016).. 


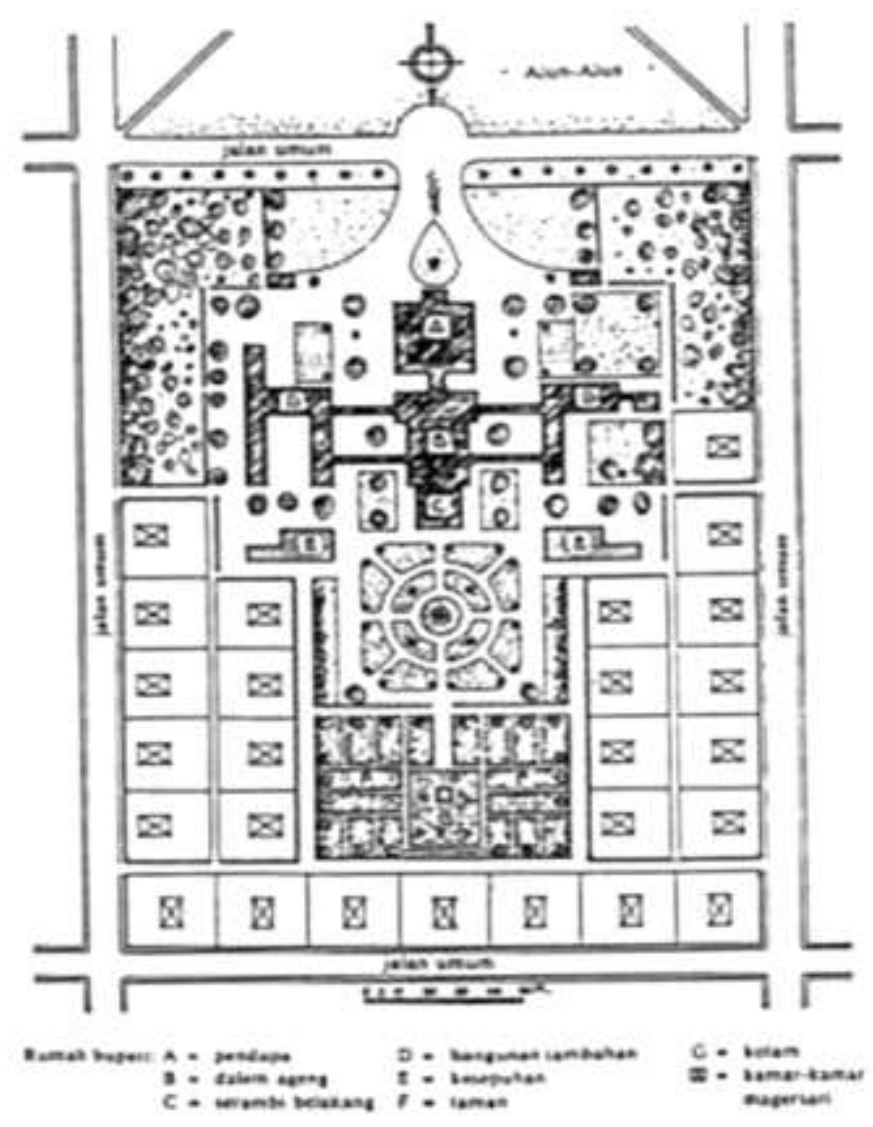

Gambar 3. : Pola hunian Magersari pada Rumah Tinggal Bupati

Pada masa Pemerintahan Kerajaan Mataram Islam.

Sumber : Kartodirdjo, 1993

\section{METODE PENELITIAN}

Kajian ini bersifat kualitatif, berdasarkan penelitian dengan menggunakan metode deskriptifideographik. Penggunaan metode deskriptif- ideographik, bertujuan menggambarkan makna susunan unsur-unsur (struktur) kota yang dijadikan latar penelitian, yakni jejak kota kerajaan Mataram Islam. Data-data akan dikumpulkan melalui 
berbagai sumber data, untuk kemudian dirumuskan deskipsi dan selanjutnya disusun suatu eksplanasi.

Penelitian ini dimulai dengan melihat keseluruhan 'latar' yang ada, sebagai kajian historis. Setelah melalui kajian historis, ditemukan unsur-unsur pembentu struktur kota yang menggambarkan ciri kerajaan Mataram Islam. Untuk mendapatkan makna dari konsep mancapat-mancalima dalam struktur kota kerajaan Mataram Islam, ditelusur dari masing-masing tempat, mulai Pajang, Kotagede, hingga Surakarta.

Proses pembahasan dilakukan melalui dua tahapan berbeda, namun secara komprehensif. Dalam rangka menelusuri susunan (struktur) unsur-unsur fisik pembentuk kota pada masa kerajaan Mataram Islam di Jawa, dilakukan dengan menganalisis data dan keterangan sejarah. Data-data tersebut, berupa dokumen peta, denah, toponim dan peninggalan fisik seperti ruang terbuka, bangunan, jalan, sungai, serta tanda-tanda lainnya. Keterangan sejarah adalah gambaran kehidupan masyarakat dan penguasanya, pada jaman kerajaan Mataram Islam tersebut. Keterangan sejarah dipergunakan untuk memberikan makna terhadap implementasi konsep mancapat-mancalima dalam struktur kota kerajaan Mataram Islam. Untuk mengkaji konsep mancapatmancalima dalam struktur kota peninggalan kerajaan Mataram Islam tersebut, dilakukan dengan gambaran lima kasus. Kelima kasus tersebut, yakni Pajang, Kotagede, Plered, Kartasura dan Surakarta, menggambarkan implementasi unusr-unsur kotanya.

\section{HASIL DAN PEMBAHASAN}

Peradaban Islam-Jawa yang dikembangkan oleh para 'wali', dalam banyak hal merupakan kelanjutan dan pembaruan Hindu-Jawa kuno. Hal tersebut terbukti dari kisah kehidupan dan perekonomian rakyat Jawa di daerah pedesaan pada awal jaman Islam, sekitar abad ke-16, yang ditemukan di dalam kisah orangorang saleh (Graaf, 1989). Dalam keterangan kisahkisah tersebut, berkaitan pula dengan keberadaan para pedagang Cina, yang pada umumnya mempunyai hubungan akrab dengan keratonkeraton pribumi. Dalam perekonomian rakyat dan pergaulan masyarakat desa, para Cina-Indo waktu itu, seperti juga kemudian hari, mempunyai kedudukan tersendiri.

Golongan masyarakat menengah beragam Islam, menempati kedudukan penting dalam struktur masyarakat pada masa kerajaan. Mereka berbeda dari golongan Keraton disatu pihak, dan berbeda dari golongan tani di pihak lain (Soeratman, 1989). Golongan menengah Islam, cukup beralasan untuk dianggap banyak berperan dalam pembaruan peradaban Jawa, di wilayah perdagangan dan di lingkungan spiritual luar Keraton. Pada masa itu, sekitar abad ke-16, perekonomian dan pergaulan rakyat di luar Keraton terpengaruh oleh agama Islam yang cenderung egaliter. Hal demikian berbeda dengan masyarakat pra-Islam di Jawa yang berkasta sakral dan berjiwa ningrat.

Pada awal abad ke-16, ibukota keraton Majapahit yang menganut Hindu-Jawa, direbut oleh pasukan Islam fanatik dari Jawa Tengah. Beberapa waktu 
kemudian, penguasa Islam dari Demak, seorang keturunan Cina, diakui sebagai Sultan. Setelah kekuasaan Sultan Demak diambil alih oleh raja Pajang, titik berat ketatanegaraan bergeser di Jawa Pedalaman. Sejak abad ke-17, pedalaman Jawa Tengah menjadi pusat politik dan kebudayaan Keraton Jawa.

Kaitan sejarah yang cukup berarti terhadap pembentukan kerajaan Mataram Islam, dimulai sat berdirinya keraton Pajang, di sebelah barat kota Surakarta. Pada masa pemerintahan kerajaan Pajang, sekitar tahun 1550, daerah Surakarta masih dikenal sebagai desa Sala, berperan sebagai penghasil beras yang cukup besar, untuk konsumsi masyarakat dan Keraton. Setelah pemerintahan keraton Pajang berakhir, kemudian berpindah ke Kotagede. Setelah keraton Mataram di Kotagede berakhir, untuk sementara pindah di Kerta, dan selanjutnya berpindah di Plered pada tahun 1613. Pada tahun 1679, keraton Mataram di plered pindah ke Kartasura. Kegiatan ekonomi semakin ramai, karena beberapa unsur asing terlibat dengan berbagai kepentingan. Unsur asing tersebut adalah bangsa Belanda (VOC) dan Cina. Setelah kerajaan di Kartasura mengalami beberapa pemberontakan, dan terakhir pemberontakan Cina, akhirnya berpindah di Sala (th.1744). Pembangunan kraton di Sala yang selesai pada tahun 1746, merubah sistem kehidupan masyarakat Sala. Semula, berupa sebuah desa Sala dengan pimpinan masyarakatnya Kiai Sala, berubah menjadi kerajaan dengan masyarakat tersusun secara hirarkis. Raja sebagai puncaknya, diikuti lapisan bangsawan, kemudian para abdi dalem, para pengiring dan para abdi (Soeratman,1989).

\section{Kota Kerajaan Pajang}

Kerajaan Pajang terletak di wilayah Surakarta, tepatnya berada di tepi sebelah barat kota Surakarta saat ini. Kraton Pajang dilingkungi oleh tembok keliling yang meliputi istana kerajaan dan alun-alun. Di sebelah kanan istana terdapat bangunan rumah tinggal untuk kesatuan pengawal istana dan serdadu. Tatanan ini menunjukkan areal yang bersifat profan dan bersifat sakral. Dapat diartikan bahwa penguasa (raja) memegang kedua sumber kekuasaan tersebut, yaitu berupa keagamaan dan militer. Raja menjadi pimpinan agama, sekaligus pemimpin bala tentaranya.

Tumenggung sebagai pimpinan pemerintahan atas nama raja, berada di sebelah barat kota (kraton). Tempat tinggal putra mahkota berlokasi di depan pasar. Unsur-unsur lain seperti kepatihan, pasar, pos pengawas pasar, terletak di sebelah utara alun-alun.

Pusat kerajaan mmenjadi pusat keramaian dan kegiatan kota. Unsur-unsur kota yang menonjol di kota kerajaan Pajang ini, berkaitan dengan kegiatan pemerintahan kerajaan, ekonomi dan permukiman. Pola jalan berfungsi menghubungkan masing-masing kegiatan tersebut. Peran sungai dalam aktifitas perdagangan, sangat besar. Ciri-ciri pada keadaan kota tersebut antara lain :

- Terjadi pertukaran (perdagangan) hasil bumi dan barang, baik intern dengan desa-desa di 
sekitar kerajaan maupun ekstern dengan daerah lain.

- Kegiatan (kehidupan) masyarakat lebih mengutamakan keagamaan, dalam hal ini agama Islam, sehingga bangunan kerajaan tidak menonjol (gigantik).

- Masyarakat di dekat pusat kerajaan bekerja sebagai pengrajin tenun, yaitu di Laweyan, berperan mendukung perdagangan kerajaan Pajang.

- Perdagangan intern terjadi di Pasar, sedangkan perdagangan

ekstern terjadi di Bandar sungai Bengawan Sala, yaitu di Semanggi.

- Kehidupan desa (desa Sala) sebagai penunjang kehidupan ekonomi kerajaan, yaitu dari hasil buminya.
Setelah berdirinya kerajaan Pajang pada akhir abad ke-16, sekaligus merupakan tanda berakhirnya kerajaan Islam yang berpusat di pesisir Utara Jawa (Demak), yang kemudian bergeser masuk ke daerah pedalaman dengan kehidupan masyarakat bercorak agraris. Seperti pada umumnya kerajaan dengan masyarakat agraris, sehingga penghasilan utama masyarakatnya merupakan aspek-aspek pertanian. Pada masa kerajaan Pajang tersebut, kehidupan dalam sistem ekonomi mereka sudah menggunakan uang dalam proses jual beli. Wilayah kerajaan Pajang, merupakan lahan subur, mengingat letak geografis kerajaan ini, berada diantara dua aliran sungai, yaitu sungai Pépé dan Déngké. Keadaan tersebut mendukung kesuburan tanah wilayah Pajang dan menjadi faktor pendukung berkembangnnya sistem Agraris di kerajaan ini. Pada masa pemerintahan Pajang sekitar abad ke 16-17 M, kerajaan ini menjadi salah satu lumbung padi terbesar dan sudah mengekspor beras keluar wilayah mereka (Graaf, 1989) 


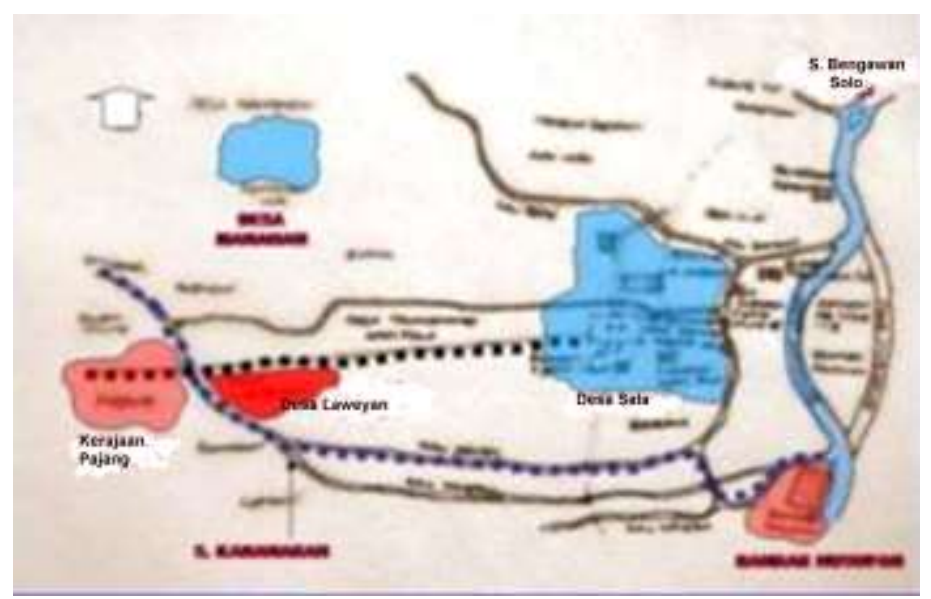

Gambar 4. : Peta orientasi kerajaan Pajang terhadap Desa Sala (Surakarta) Sumber : http//wawasansejarah.com/kerajaan-pajang/

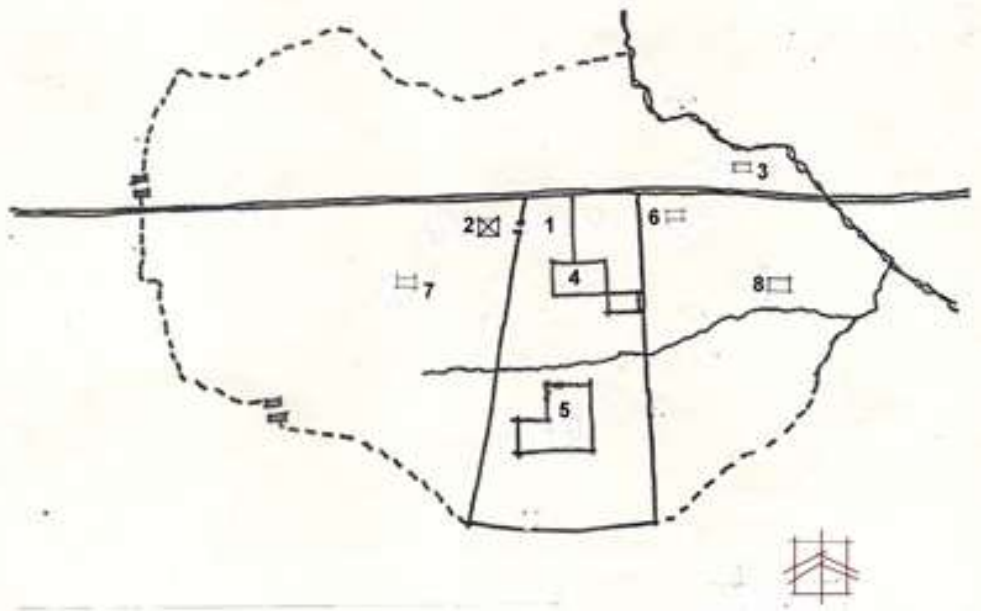

Keterangan:

1.Alun-alun

2.Masjid

3.Pasar

4.Siti Inggil

5.Dalem Keraton

6.Rumah Pangeran

7.Rumah Pejabat Keraton

8.Rumah Abdi-Dalem.

Gambar 5. : Peta Kota kerajaan Pajang

Sumber : Museum Radya Pustaka Surakarta. 


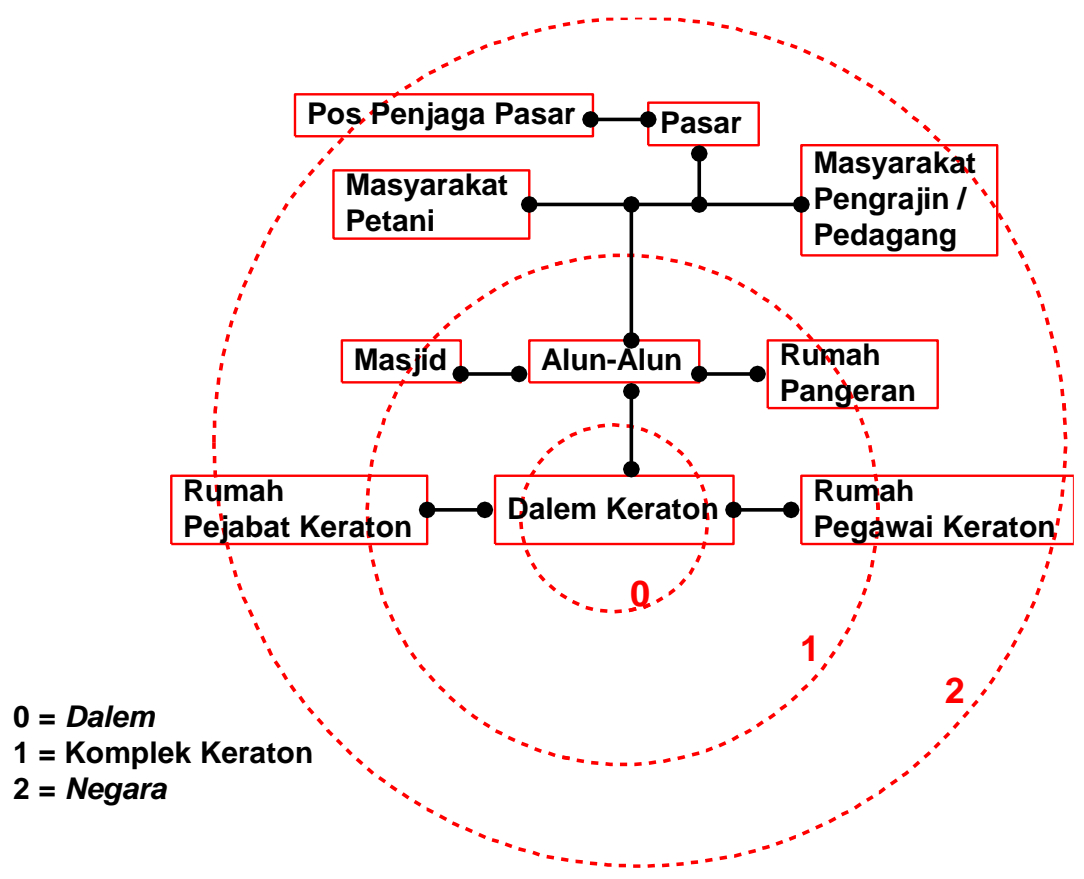

Gambar 6. : Lingkaran Tata Ruang kota kerajaan Pajang.

Sumber : hasil analisis.

\section{Kota Kerajaan Kotagede}

Kotagede merupakan ibu kota kerajaan Mataram Islam yang pertama kali. Kota ini didirikan pada masa kekuasaan kerajaan Pajang (sebelum th.1586), oleh Kyai Ageng Pamanahan. Pendiri Kotagede ini adalah seorang pegawai pemerintah yang terpandang, di kerajaan Pajang. Karena dianggap berjasa, ia mendapat kepercayaan mengurus daerah Mataram. Pada awalnya Kotagede ini berfungsi sebagai pusat administrasi, sehubungan dengan tugas Kyai Ageng Pamanahan.
Pada tahun 1586 Panembahan Senopati, putra Kyai Ageng Pamanahan, memproklamirkan kedudukan sebagai raja. Setelah berhasil menundukkan pemerintahan Pajang, kadaulatan sebagai raja Mataram diakui. Kedudukan Kotagede sebagai pusat pemerintahan kerajaan Mataram, berlangsung hanya sampai tahun 1625. Terletak di sebelah tenggara (sekitar $4 \mathrm{~km}$ ) dari kota Yogyakarta sekarang.

Kotagede sebagai ibukota kerajaan menunjukkan struktur kota yang berciri organis (tidak teratur). Jaringan jalan yang tidak teratur (organis) merupakan 
ciri utama permukiman di daerah pedesaaan. Kondisi demikian berkaitan dengan Kotagede bukan sebagai ibu kota kerajaan, pada awalnya. Hal yang menunjukkan orientasi secara jelas hanyalah jalur jalan Utara-Selatan. Pasar terletak di sebelah selatan jalur jalan arah Timur-Barat, hal ini berbeda dengan kota Mataram-lainnya. Komplek masjid (dengan makam, dan pemandian) terletak di sebelah barat kampung Alun-alun sekarang. Letak kraton yang diperkirakan sebagai kampung Kedaton sekarang, berada di sebelah selatan alun-alun. Sebelah barat pasar, tardapat komplek permukiman pedagang/pengrajin. Masyarakat Kotagede pada masa kerajaan, benyak yang berprofesi sebagai pengrajin. Masyarakat pengrajin tersebut banyak yang bermukim di sekitar Keraton.

Pola jalan yang berarah ke timur dan barat, berperan utama secara ekonomis, menghubungkan permukiman masyarakat pedagang, pengraiin dan petani. Pola jalan kearah utara berperan utama secara administratip, menghubungkan Kotagede dengan keraton Pajang. Pasar sebagai pusat kegiatan perekonomian kota. Kraton dikelilingi oleh tembok, sedangkan permukiman para abdi-dalem berada di luar tombok keraton. Rumah-rumah para abdi-dalem dan pejabat tinggi keraton tersebut, banyak terdapat di dekat keraton.

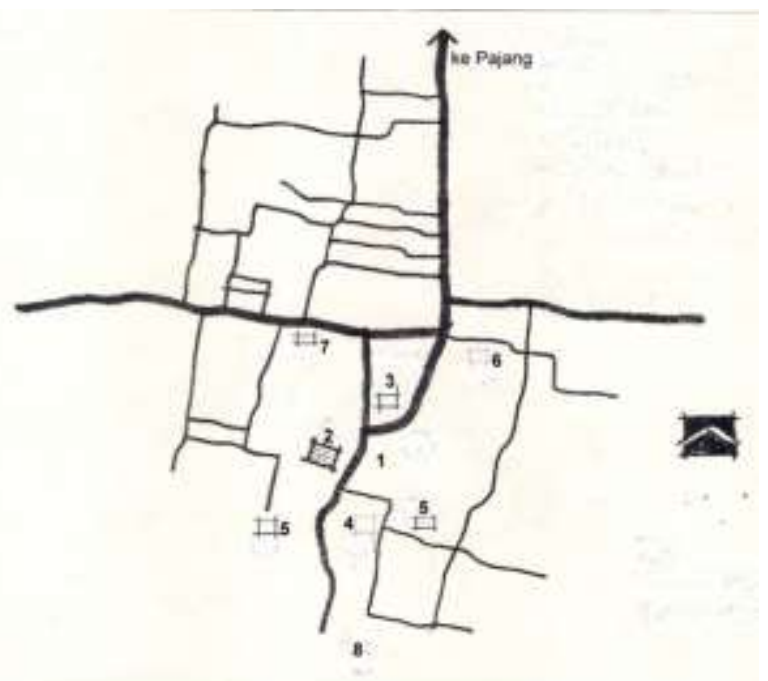

\author{
Keterangan: \\ 1.Alun-alun \\ 2.Masjid \\ 3.Pasar \\ 4.Dalem Keraton \\ 5.Permukiman Abdi-dalem \\ 6.Permukiman Pengrajin \\ 7.Permukiman Pedagang \\ 8.Kebonan.
}

Gambar 7. : Peta Kota kerajaan Kotagede

Sumber : Nakamura, 1983:234. 


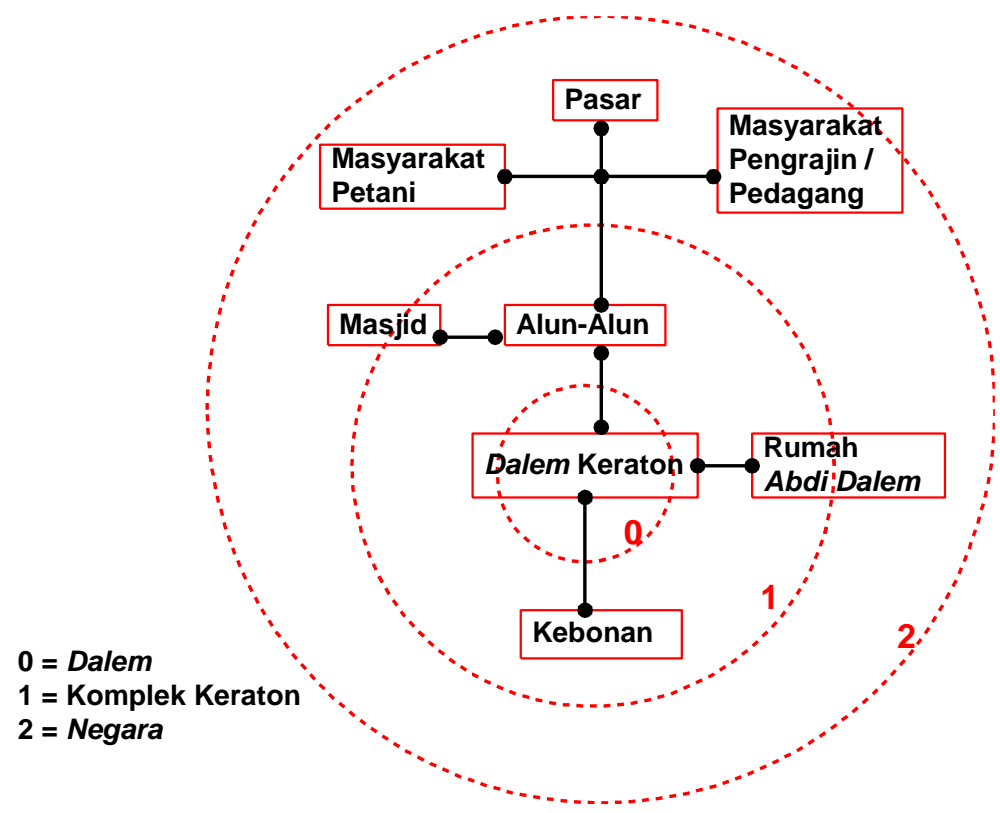

Gambar 8. : Lingkaran Tata Ruang kota kerajaan Kotegede.

Sumber : hasil analisis.

\section{Kota Kerajaan Plered}

Plered sebagai ibu kota kerajaan Mataram, dibangun pada masa kejayaan Sultan Agung, sekitar tahun 1625. Terletak sekitar 5-7 km sebelah Timur Yogyakarta. Bersamaan dengan pembangunan keraton di Plered, dibangun pula komplek makam di Imogiri. Imogiri terletak sekitar $3 \mathrm{~km}$ sebelah selatan Plered, merupakan daerah perbukitan. Pada masa pemerintahan Sultan Agung, kerajaan Mataram yang memperluas pengaruh sampai Jawa Timur, memindahkan pusat kekuasaan dari Kotagede ke Kerto. Setelah kekuasaan diperintah Amangkurat I, anak Sultan Agung, kemudian memindahkan Keraton dari Kerto ke Pleret pada tahun 1647.

Gambaran kota Plered dijelaskan dengan rinci dalam laporan perjalanan Van Goens pada tahun 1655 
(dalam: Jo Santoso, 1984: --- ), dari Semarang ke Plered.

Dalam perjalanan menuju Plered sekitar 18 - 19 mil dari kota pelabuhan Semarang, terletak pintu gerbang pertama, disebut Selimbi. Pada pintu gerbang ini terdapat sebuah benteng, yang dibuni sekitar 1500 - 1600 orang. Dengan dijaga oleh para prajurit keraton, semua yang lewat gerbang dicatat oleh juru tulis. Sekitar 1 - 1,5 mil dari gerbang Selimbi, terbentang daerah Mataram yang subur, sawah sangat luas hingga batasnya tidak tampak. Desa-desa sangat subur banyak ditemui sepanjang jalan. Diantara sawah-sawah ditemui perbukitan yang ditanami pohon buab-buahan. Diperkirakan pintu gerbang Selimbi merupakan pintu masuk wilayah negara agung Mataram. Jalan antara gerbang Selimbi dan gerbang Tadie (gerbang masuk kedua), berjarak sekitar 7 mil. Setelah gerbang kedua terlihat pegunungan mengitari pusat kerajaan Plered. Digambarkan oleh Van Goens bahwa desa-desa diantar kedua pintu gerbang tersebut, padat penghuni. Setiap desa berpenduduk sekitdr 100 - 150 orang, babkan ada yang berpenghuni sekitar 1000 - 1500 orang. Pusat kerajaan dicapai setelah melalui garbang ketiga, yang dinamakan Kaliajir. Dari gerbang ini terdapat jalan menuju istana raja, sepanjang 2 mil. Antara gerbang Kaliajir dan istana raja, banyak ditemui rumah para pangeran dan berbagai residen. Pagar kota diperkirakan berukuran luas $2 \times 2$ mil, dengan ketinggian tembok sekitar 6 - 7 meter. Di dalam tembok keraton terdapat bangsal kencana, rumah jaga Gedong Kemuning, masjid keraton Suranata, Gedong Kedondong dan sumur Guleng tempat memandikan keris pusaka. Di sebelah utara komplek keraton terdapat alun-alun berukuran sekitar $300 \times 400$ m, dengan Masjid di sebelah baratnya. Didalam komplek masjid terdapat makam.

Desa Kauman yang sekarang ada di sekitar masjid, diperkirakan dibuni oleb para pemuka agama dan pegawai masjid. Rumah-rumah para pangeran terletak di sebelah utara alun-alun, menuju gerbang Kaliajir. Di sekitar desa Segarayasa, dulu terdapat danau buatan, terletak di sebelah selatan keraton. Di tengah danau (Segarayasa) tersebut terdapat sebuab pulau, dipergunakan untuk meditasi dan sembabyang raja.

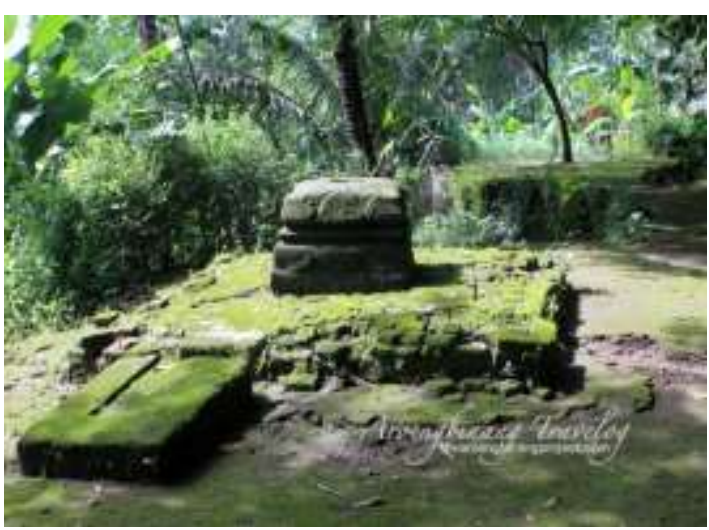

Gambar 9: Batu Umpak di Situs Plered, bekas umpak bangunan Keraton Sumber: https://www.thearoengbinangproject.com/jejakmataram-di-situs-kerto-pleret/ 


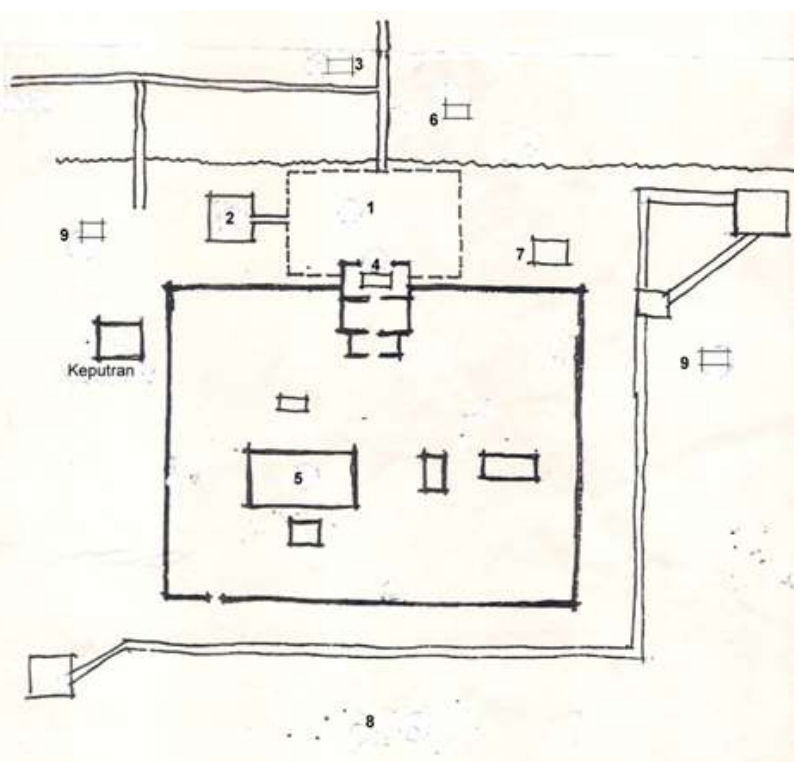

\section{Keterangan:}

1.Alun-alun

2.Masjid

3.Pasar

4. Siti Inggil

5.Dalem Keraton

6.Rumah Pangeran

7.Rumah Pejabat

Keraton

8.Segarayasa

9.Permukiman Abdi-

dalem

Gambar 10. : Peta Kota kerajaan Plered

Sumber : Museum Radya Pustaka Surakarta 


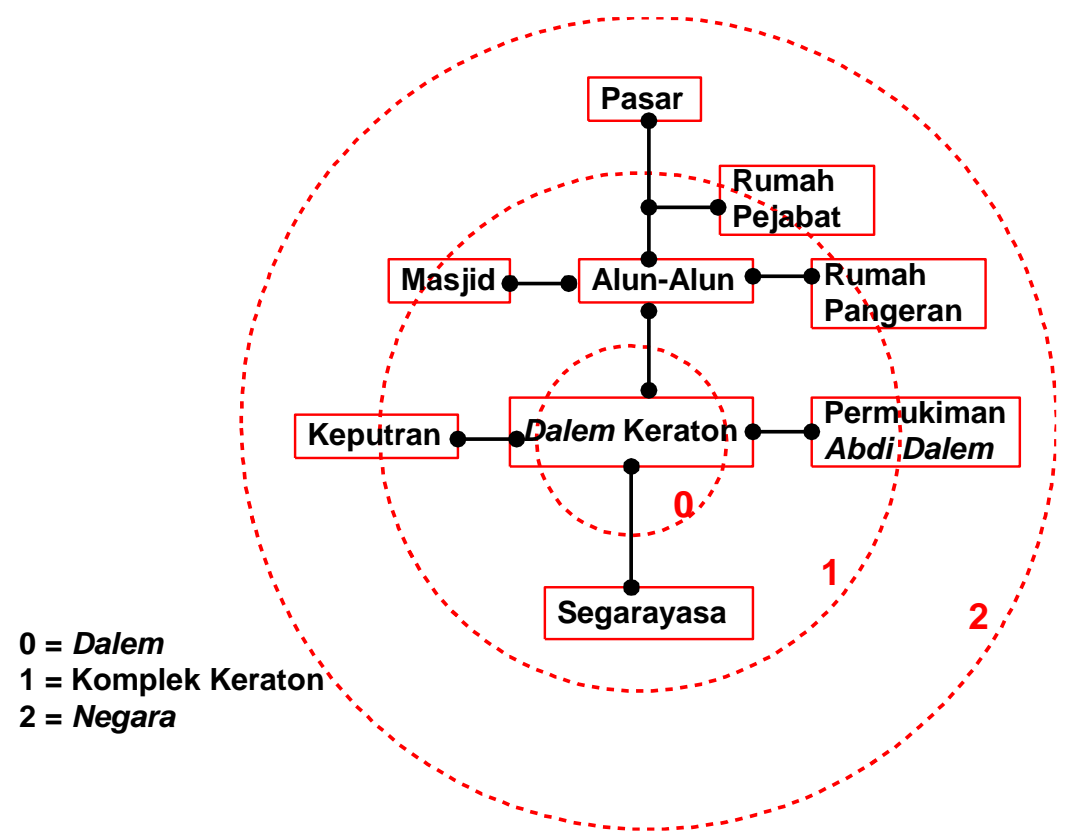

Gambar 11. : Lingkaran Tata Ruang kota kerajaan Plered.

Sumber : hasil analisis.

\section{Kota Kerajaan Kartasura}

Pada tahun 1674 teriadi pemberontakan di Plered oleh pasukan daerah pesisir dan Madura. Pemberontakan dipimpin oleh Trunojoyo. Raja Amangkurat I yang memerintah waktu itu melarikan diri hingga meninggal di Tegalwangi. Amangkurat II sebagai putra mahkota dibantu oleh Belanda, berhasil mengalahkan pemberontak. Selanjutnya ia dinobatkan sebagai raja, dengan membangun ibu kota baru di Kartasura.
Seperti halnya masa kerajaan sebelumnya, pusat kegiatan berada di sekitar keraton. Kartasura terletak di bagian barat, luar kota Surakarta sekarang. Kegiatan ekonomi semakin ramai, karena beberapa unsur asing terlibat, dengan berbagai kepentingannya. Unsur-unsur asing tersebut adalah Kolonial (Belanda), Cina dan Arab. Perkembangan selanjutnya, yang berperan kuat adalah bangsa Belanda, dengan pemerintahan Kolonialnya. Unsur-unsur kota masih diwarnai oleh kegiatan ekonomi, pemerintahan dan permukiman. Diantaranya yang paling berkembang adalah 
pusat-pusat kegiatan ekonomi. Peran sungai Bengawan Solo masih sangat berarti, dalam perdagangan internal maupun eksternal. Pasar yang terletak di bagian utara alun-alun, berfungsi utama dalam perdagangan internal.

Unsur-unsur kota di Kartasura lebih banyak berkembang daripada kota-kota kerajaan sebelumnya. Di sebelah luar Keraton terdapat banyak rumah-rumah pangeran dan pejabat tinggi Keraton. Pada masa kerajaan Kartasura ini, mulai terdapat alun-alun Selatan sebagai pengganti Segarayasa.
Segarayasa bermakna simbolis sebagai sumber kehidupan. Alun-alun selatan sebagai pengganti Segarayasa, bersifat profan. Alun-alun utara, yang menjadi satu kesatuan dengan masjid, dianggap bersifat sakral. Keraton dengan demikian mempunyai dua orientasi, yaitu orientasi yang bersifat sakral dan bersifat profan. Poros jalan utara - selatan bersifat sakral, sedangkan pola jalan arah timur - barat bersifat profan. Jaringan jalan yang terbentuk, lebih dominan kearah timur - barat, menghubungkan tempat-tempat ekonomis seperti Pajang, Laweyan, Sala, hingga Bandar Semanggi

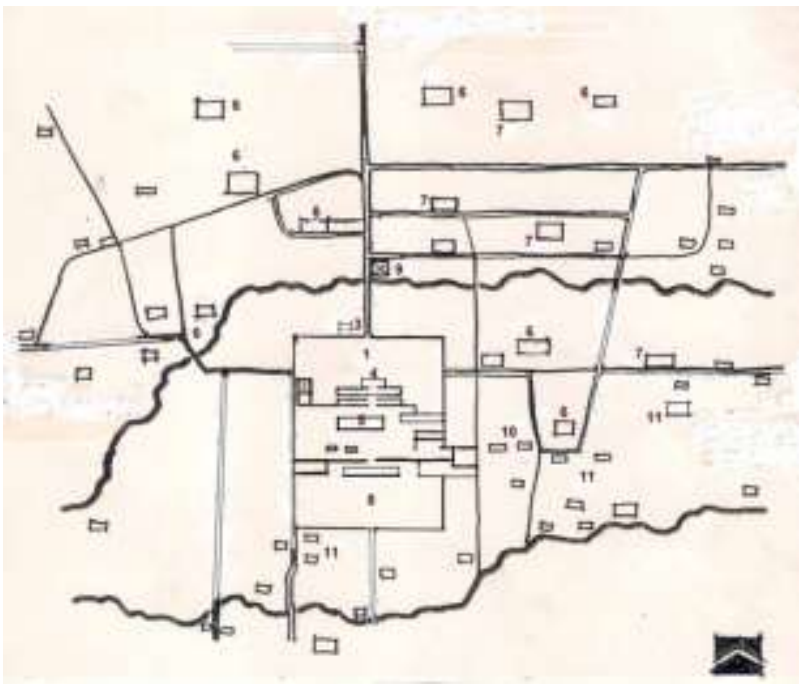

Keterangan:

1.Alun-alun Utara

2.Masjid

3.Pasar

4. Siti Inggil

5.Dalem Keraton

6.Rumah Pangeran

7.Rumah Pejabat Keraton

8.Alun-alun Selatan

9.Benteng Belanda

10.Pecinan

11.Permukiman Abdi-dalem

.Gambar 12.: Peta Kota Kerajaan Kartasura

Sumber: Museum Radya Pustaka Surakarta. 


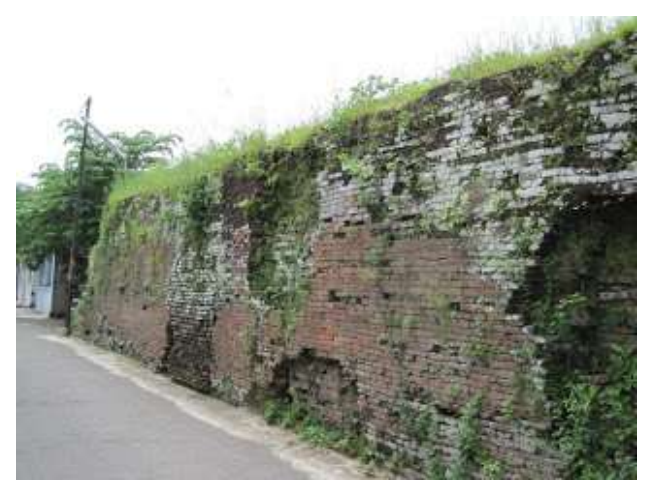

Gambar 13: Benteng Keraton Kartasura Sumber:

http://tarabuwana.blogspot.co.id/2012/01 /petilasan-kraton-kartosuro

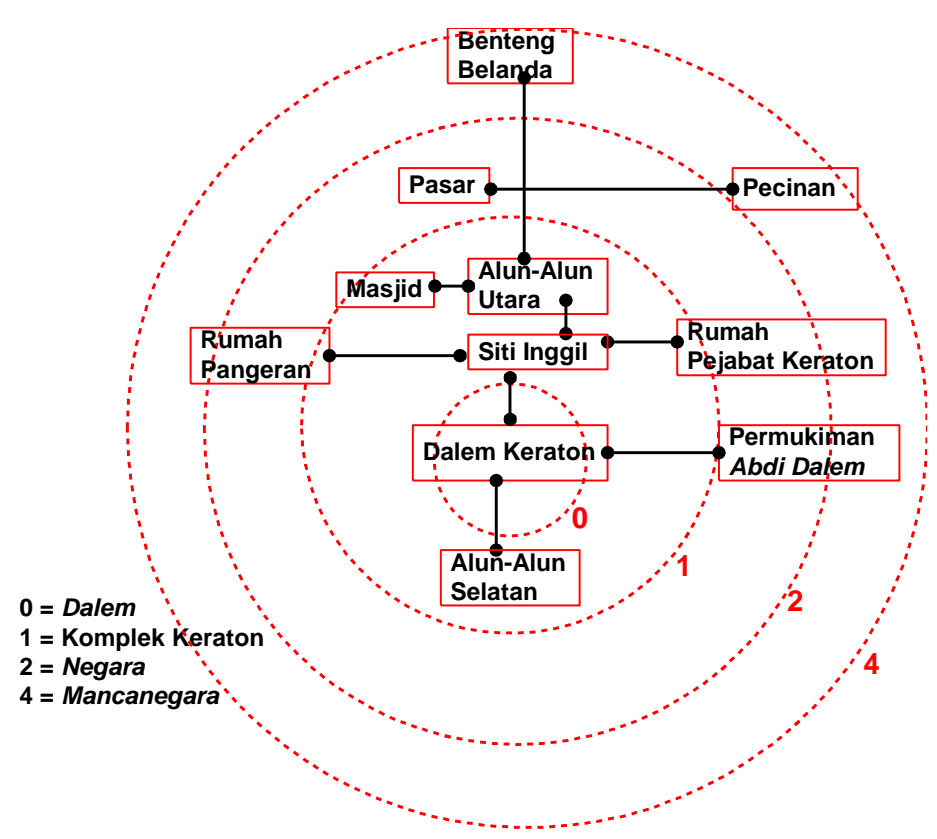

Gambar 14. : Lingkaran Tata Ruang kota kerajaan Kartasura. Sumber : hasil analisis.

Setelah Kartasura yang memiliki dua buah alun-alun, demikian juga Surakarta. Kedua alun-alun di Surakarta, yaitu Utara dan Selatan, memiliki luas sama besar, sekitar 400 x 300 meter. Alun-alun tersebut berupa lapangan pasir halus, masing-masing di tengahnya ditanami dua buah pohon Beringin. Komplek keraton terletak diantara kedua alun-alun tersebut.

Keraton bagian dalam (Dalem) terpisah oleh tembok setinggi $3 \mathrm{~m}$, dengan tembok keraton yang kedua (benteng). Di dalam benteng keraton ini, Dalem 
terpisah dengan bangunan keraton lainnya. Di antara tembok keraton yang pertama dan kedua, dihuni oleh para pangeran yang duduk dalam pemerintahan dan para abdi dalem. Ciri menonjol dalam struktur kota Surakarta pada masa ini adalah peralihan daerah perkotaan dan daerah pedesaan, yang begitu menyatu. Informasi tentang batas awal kota pada masa itu memang belum ada. Diduga akibat dari ketidak jelasan batas kota, sehingga kota Surakarta berkembang secara tidak teratur (organis). Dua buah jalan yang cukup lebar, memanjang kearah Timur - Barat, membelah kota Surakarta menjadi belahan Selatan dan Utara. Istana (keraton), masjid Agung, dan rumah para pangeran, terletak di sebelah selatan kota. Bagian selatan dari belahan ini berkembang ke arah barat.

Di bagian utara dari belahan jalan tersebut, terdapat sarana-sarana profan, seperti Kepatihan dan pasar. Di sebelah kanan dari poros jalan Utara - Selatan, ditempatkan permukiman orang asing (Cina, Belanda dll). Bagian ini selanjutnya berkembang ke arah timur. Juga di belahan utara ini, Yang berada di bagian barat poros jalan Utara-Selatan, terdapat permukiman orang Bali (Kebalen). Keberadaan istana Mangkunegaran merupakan hal Yang khusus, mengingat pendiriannya berdasarkan perjanjian tahun 1757 antara Paku Buwana III dan Raden Mas Said. Dalam perjanjian ini Mas Said bersedia menghentikan pemberontakan, dengan imbalan mendapat wilayah seluas 4000 cacah, serta ijin membangun istana di Surakarta.
Komplek keraton beserta alun-alun menunjukkan ciri bagian kota yang sakral. Di bagian ini kekuasaan raja (susuhunan Paku Buwana) merupakan kekuasaan yang absolut. Permukiman orang asing yang beragama lain dan daerah eksteritorial seperti Mangkunegaran dan 'kota Eropa' terdapat di bagian belahan utara kota. Kedudukan Mangkunegaran menunjukkan pengakuannya atas status raja Mataram, yaitu Paku Buwana dan Hamengku Buwana. Hal ini terlihat dari struktur tata ruang Mangkunegaran yang berbeda dengan struktur kerajaan Mataram (Kasunanan).

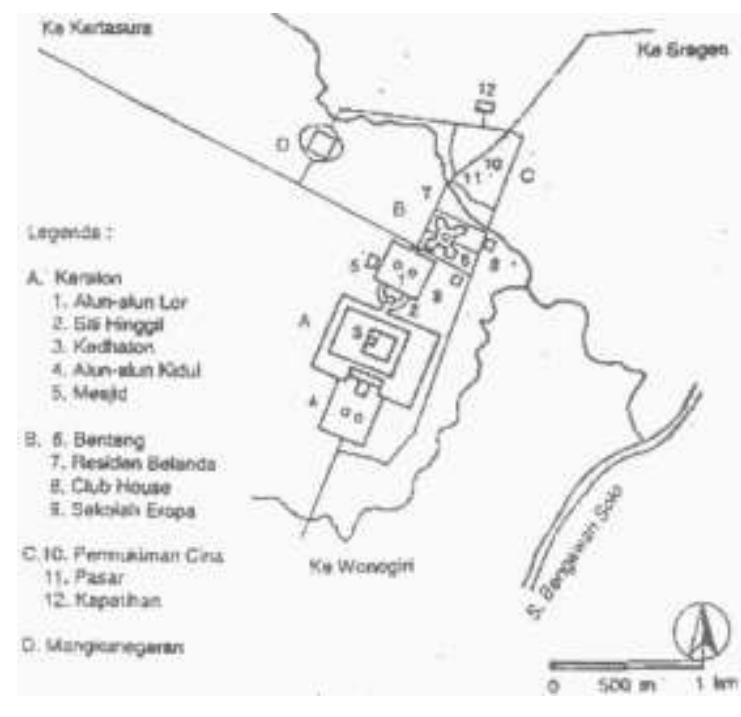

Gambar 15.: Peta Kota Kerajaan Surakarta Sumber: Museum Radya Pustaka Surakarta 


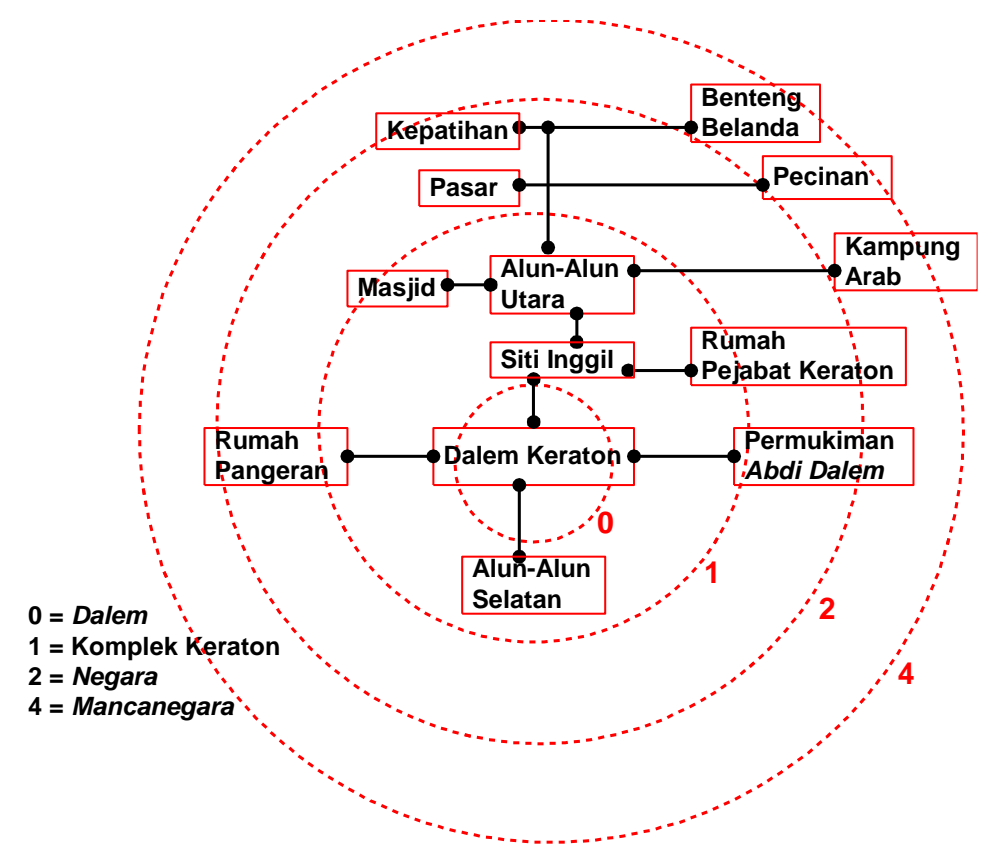

Gambar 16.: Lingkaran Tata Ruang Kota Kerajaan Surakarta Sumber: hasil analisis.

\section{KESIMPULAN}

Dari hasil kajian dan pembahasan tersebut, dapat diambil beberapa kesimpulan, sebagai berikut:

1. Terdapat unsur-unsur yang utama pembentuk struktur kota kerajaan Mataram Islam, berupa : Dalem Keraton, Alun-alun, Masjid, tempat tinggal Pangeran dan pejabat Keraton, permukiman Abdi-dalem dan Pasar. Unsurunsur kota tersebut, tersusun dalam konsepsi tradisional sakral dan profan.

2. Transformasi konsep mancapat-mancalima dalam struktur kota kerajaan Mataram Islam, tersusun dalam superposisi antara pola grid sumbu "Utara-Selatan" dan "Timur-Barat", dengan lingkaran- 
lingkaran imajiner. Sumbu "Utara-Selatan" bersifat sakral, sedangkan sumbu "TimurBarat" bersifat profan. Sebagai pusat adalah Dalem Keraton, yang bermakna simbolik sebagai pengendalidan sekaligus penyelaras tatanan kehidupan di "Negara Agung".

\section{DAFTAR PUSTAKA}

Behrend, T.E. (1982), Kraton and Cosmos in Traditional Java (Tesis: ---)

Catanese, A.J dan Snyder, J.C. (1986) Pengantar Perencanaan Kota (Jakarta: Terjemahan, Erlangga).

Graaf, H.J.D dan Pigeaud, Th.G.Th (1989) Kerajaan Kerajaan Islam di Jawa (Jakarta: Grafiti Pers).

Gesick, L. (1989) Pusat, Simbol dan Hirarki Kekuasaan (Jakarta: terjemahan Ongkhokham, Yayasan Obor)

Junianto (2017) Pengarub Kerajaan Islam Terdahap Pola Bentuk. Kota Pasuruan (Makassar: Jurnal Plano Madani, Volume 6 Nomor 1).

Koentjaraningrat (1992) Kebudayaan Mentalitas dan Pembangunan (Jakarta: PT Gramedia Pustaka Utama).

Kartodirdjo, S. (1993) Perkembangan Peradaban Priyayi (Yogyakarta: Gadjah Mada University Press).

Mangunwijaya (1988), Wastu Citra Jakarta: Gramedia).

Murtoyoso, S. (1993) Sejarah Arsitektur Kota di Kawasan Budaya Pesisir (Surabaya: Seminar Pelestarian Arsitektur Kota).
Muhadjir, N. (1990) Metode Penelitian Kualitatif (Yogyakarta: Rake Sarasin).

Santoso, J. (1984), Konsep Struktur dan Bentuk Kota di Jawa s/d Abad XVIII (Disertasi).

Soeratman, D. (1989), Kebidupan Dunia Kraton Surakarta 1830-1939 (Yogyakarta: Tamansiswa).

Sumarlina, N.S. (1993) Pola Tata Kota Surakarta Awal dan Perkembangannya (Yogyakarta: Fakultas Sastra UGM).

Tanudjaja, C.J.S. (1991) Suatu Telaah Tentang Saka Bangunan Tradisional Jawa di Kotamadya Yogyakarta (Bandung: Pasca Sarjana S2 Arsitektur, ITB).

Tjahjono, G. (1988) Cosmos, Center, and Duality in Javanese Architectural Tradition: The Symbolic Dimensions of House Shapes in Kotagede and Surroundings (Berkeley: University of California). 